\title{
Binder Jet Tooling for Automotive Lighting Industry
}

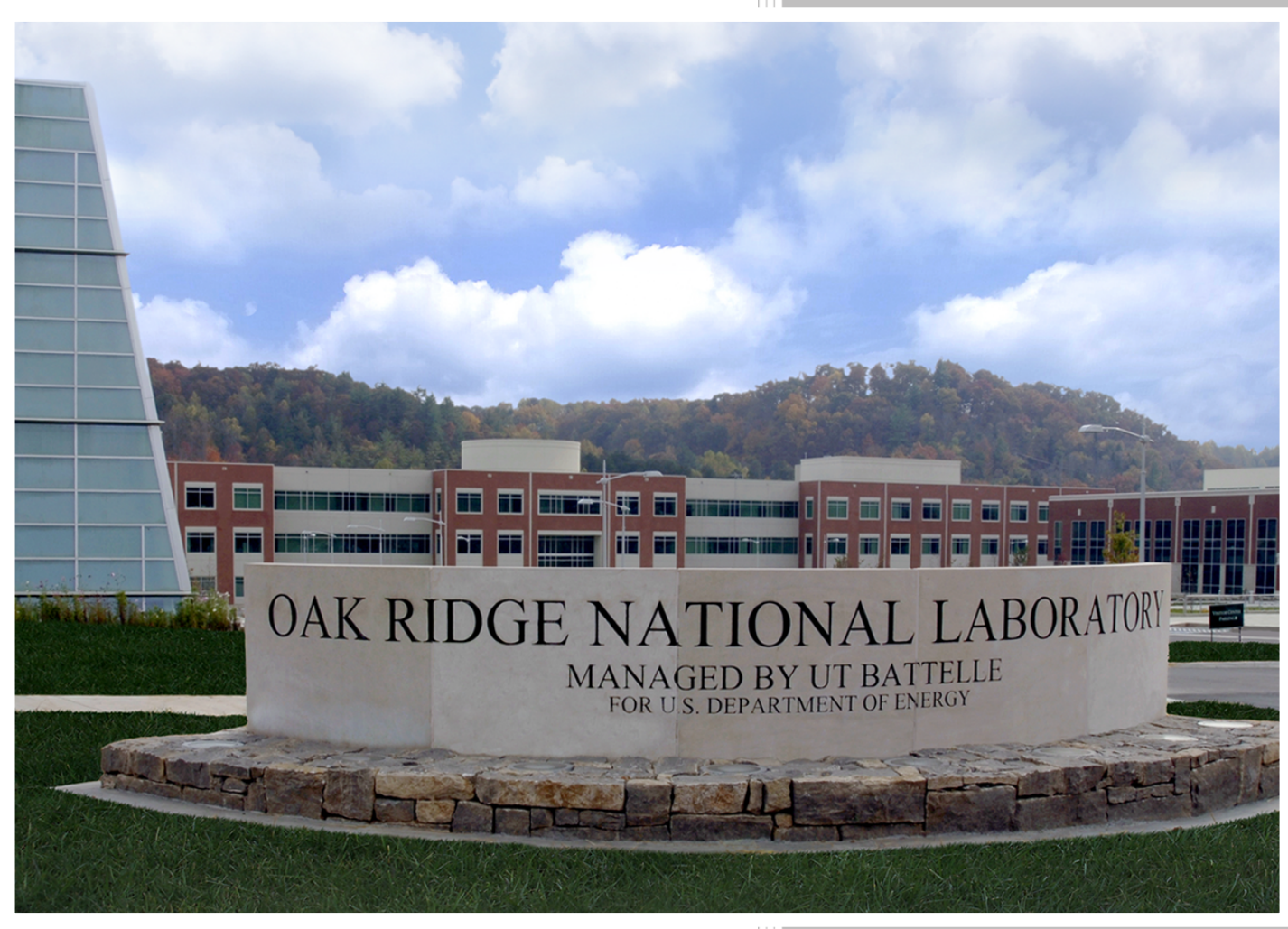

Amy Elliott

December 31, 2019

CRADA FINAL REPORT

NFE-18-07277

Approved for Public Release.

Distribution is Unlimited. 


\title{
DOCUMENT AVAILABILITY
}

Reports produced after January 1, 1996, are generally available free via US Department of Energy (DOE) SciTech Connect.

Website www.osti.gov

Reports produced before January 1, 1996, may be purchased by members of the public from the following source:

\author{
National Technical Information Service \\ 5285 Port Royal Road \\ Springfield, VA 22161 \\ Telephone 703-605-6000 (1-800-553-6847) \\ TDD 703-487-4639 \\ Fax 703-605-6900 \\ E-mail info@ntis.gov \\ Website http://classic.ntis.gov/
}

Reports are available to DOE employees, DOE contractors, Energy Technology Data Exchange representatives, and International Nuclear Information System representatives from the following source:

Office of Scientific and Technical Information

PO Box 62

Oak Ridge, TN 37831

Telephone 865-576-8401

Fax 865-576-5728

E-mail reports@osti.gov

Website http://www.osti.gov/contact.html

\begin{abstract}
This report was prepared as an account of work sponsored by an agency of the United States Government. Neither the United States Government nor any agency thereof, nor any of their employees, makes any warranty, express or implied, or assumes any legal liability or responsibility for the accuracy, completeness, or usefulness of any information, apparatus, product, or process disclosed, or represents that its use would not infringe privately owned rights. Reference herein to any specific commercial product, process, or service by trade name, trademark, manufacturer, or otherwise, does not necessarily constitute or imply its endorsement, recommendation, or favoring by the United States Government or any agency thereof. The views and opinions of authors expressed herein do not necessarily state or reflect those of the United States Government or any agency thereof.
\end{abstract}


Energy and Transportation Science Division

Advanced Manufacturing Office

\title{
Binder Jet Tooling for Automotive Lighting Industry
}

\author{
Authors \\ Amy Elliott \\ Joseph Wing
}

\author{
Date Published: \\ December 2019 \\ Prepared by \\ OAK RIDGE NATIONAL LABORATORY \\ Oak Ridge, Tennessee 37831-6283 \\ managed by \\ UT-BATTELLE, LLC \\ for the \\ US DEPARTMENT OF ENERGY \\ under contract DE-AC05-00OR22725
}

Approved For Public Release 



\section{CONTENTS}

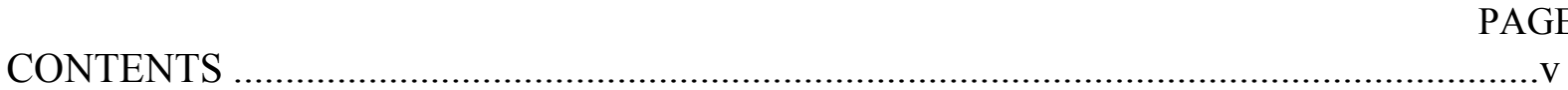

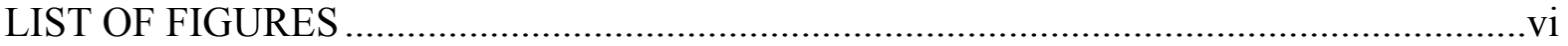

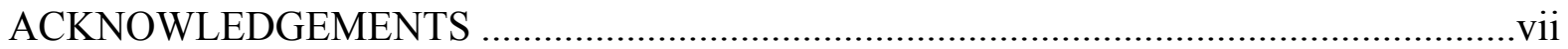

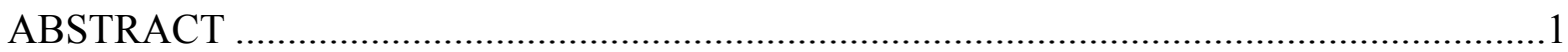

1. BINDER JET TOOLING FOR AUTOMOTIVE LIGHTING INDUSTRY ...................1

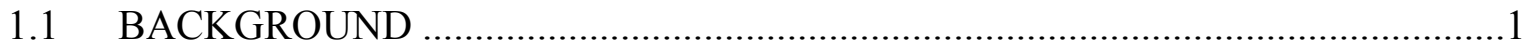

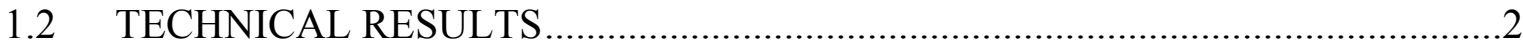

1.2.1 MOLD DESIGN, MANUFACTURE, AND POLISHING ..................................

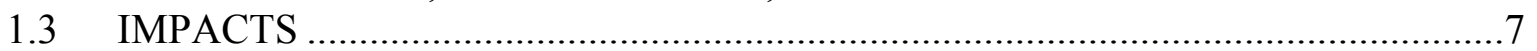

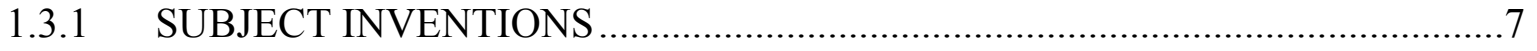

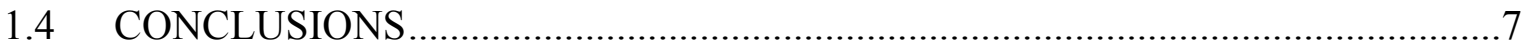

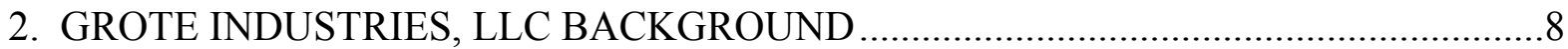

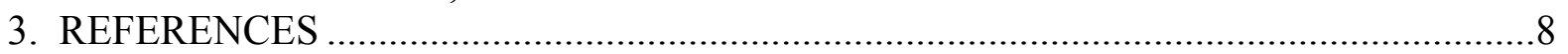

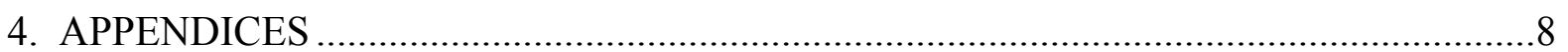

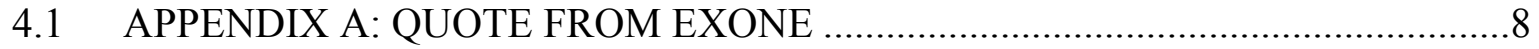

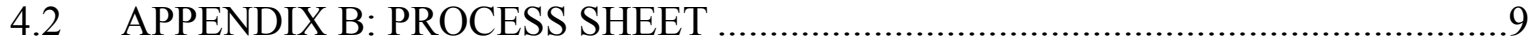




\section{LIST OF FIGURES}

Figure 1. Binder jet process cycle for producing bronze-steel metal matrix composite parts...1

Figure 2. A) Polished surface and B) Mounting used for polishing...................................2

Figure 3. Surface roughness profile.......................................................................

Figure 4. Cross Section of Printed and Infiltrated SS316. Shadows indicate uneven material

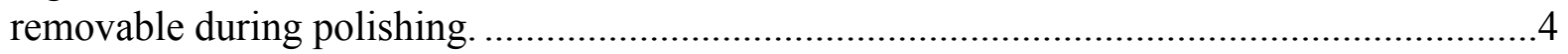

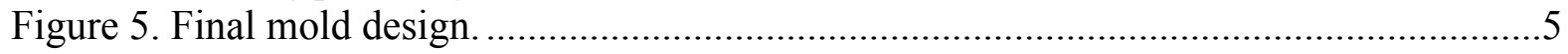

Figure 6. One half of the fabricated mold prior to polishing...........................................5

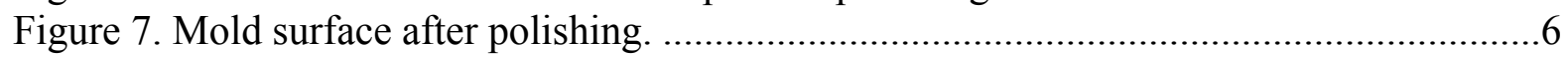




\section{ACKNOWLEDGEMENTS}

This CRADA NFE-18-07277 was conducted as a Technical Collaboration project within the Oak Ridge National Laboratory (ORNL) Manufacturing Demonstration Facility (MDF) sponsored by the US Department of Energy Advanced Manufacturing Office (CPS Agreement Number 24761).

Opportunities for MDF technical collaborations are listed in the announcement "Manufacturing Demonstration Facility Technology Collaborations for US Manufacturers in Advanced

Manufacturing and Materials Technologies" posted at http:/web.ornl.gov/sci/manufacturing/docs/FBO-ORNL-MDF-2013-2.pdf. The goal of technical collaborations is to engage industry partners to participate in short-term, collaborative projects within the Manufacturing Demonstration Facility (MDF) to assess applicability and of new energy efficient manufacturing technologies. Research sponsored by the U.S. Department of Energy, Office of Energy Efficiency and Renewable Energy, Advanced Manufacturing Office, under contract DE-AC0500OR22725 with UT-Battelle, LLC. 


\begin{abstract}
The goal of this collaborative project between Oak Ridge National Laboratory's (ORNL) Manufacturing Demonstration Facility (MDF) and Grote Industries, LLC was to develop additively manufactured tooling to produce lighting products in a production environment. The project explored the use of metal powder bed systems to rapidly manufacture moderately sized injection molding tools (less than 8" x 8" x 2") for automotive lamps. The team designed the mold (male and female), manufactured the mold using the binder jet process, experimented with finishing processes, manufactured parts using the molds, and monitored the wear on the mold to predict life.
\end{abstract}

\title{
1. BINDER JET TOOLING FOR AUTOMOTIVE LIGHTING INDUSTRY
}

This phase 1 technical collaboration project (MDF-TC-2018-137) began on June 18, 2018 and concluded on December 31, 2019. The collaboration partner Grote Industries, LLC is a medium sized business.

\subsection{BACKGROUND}

Binder jetting is a type of additive manufacturing (AM) technology that provides low-cost, highthroughput processing of high-utility materials into custom shapes. The opportunity exists to utilize binder jetting to produce tooling for the plastic-molding industry, and such tooling would be low-cost and have a shorter lead time compared to current approaches. The binder jet process works by repeatedly spreading a powder feedstock into thin layers and then selectively "sticking" the powder together by depositing a binder into the powder layer with an inkjet print head. The result is a volume of metal powder and binder arranged in the shape of the desired part(s).

From this point, the "green" parts are removed from the build volume in a process called "depowdering" and set up for post-processing. Post processing is necessary to give the printed part mechanical properties as the green parts are merely loosely bound metal powder. For this project, the printed powder was Stainless Steel 420 and the post-processing technique utilized was bronze infiltration. The stainless-steel green part was placed in a crucible alongside a pile of bronze beads, and the two materials were heated together to a temperature sufficient to melt the bronze. Once melted, the bronze forms a liquid puddle and wicks into the porous stainless-steel part, infiltrating the voids between the particles. This produces a nearly-fully dense metal material known as a metal matrix composite. Figure 1 depicts the process cycle just described.

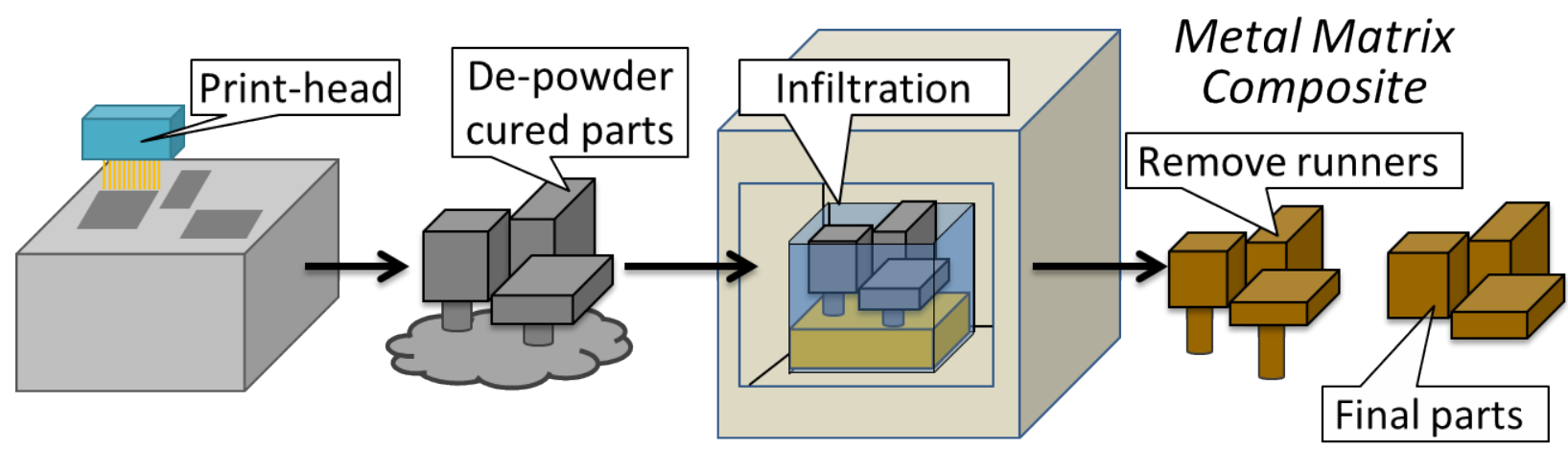

Figure 1. Binder jet process cycle for producing bronze-steel metal matrix composite parts. 
The objective of this project was to demonstrate the ability to use the binder jet process to rapidly and inexpensively manufacture injection mold tooling for the automotive lighting industry. The impact would shorten the development cycle by months and allow tooling to be done in the United States instead of China. The project explored the use of metal powder bed systems to rapidly manufacture moderate sized injection molding tools (less than 8 " x 8 " x 2") for automotive lamps. The goal was to quantify the cost (material, machine time, and labor) and durability (cycles of parts) of a binder jet additively manufactured injection molding tool. In addition, the project explored methods to rapidly and inexpensively achieve a target class A automotive finish (polishing, coatings). This project designed and manufactured the injection molding tool using the binder jet process. ORNL manufactured two sets of molds. One mold was used to explore direct polishing of the mold, while other mold was used to explore coatings to achieve the target surface finish. The molds were manufactured using the conventional low-cost steel powders with bronze back infiltration.

\subsection{TECHNICAL RESULTS}

ORNL performed a preliminary experiment with available polishing equipment to understand the viability of achieving a Society of the Plastics Industry (SPI) A-1 class polished surface finish on bronze-steel infiltrated parts. A small sample of bronze-steel was produced and polished via standard metallography techniques [1], meaning the metal part was mounted in epoxy and polished using a series of polishing media and steps. This procedure will typically produce mirror-like finishes similar to SPI A-1 class. Figure $2 \mathrm{~A}$ below is an image of that polished surface and Figure $2 \mathrm{~b}$ is the type of epoxy mounting used.
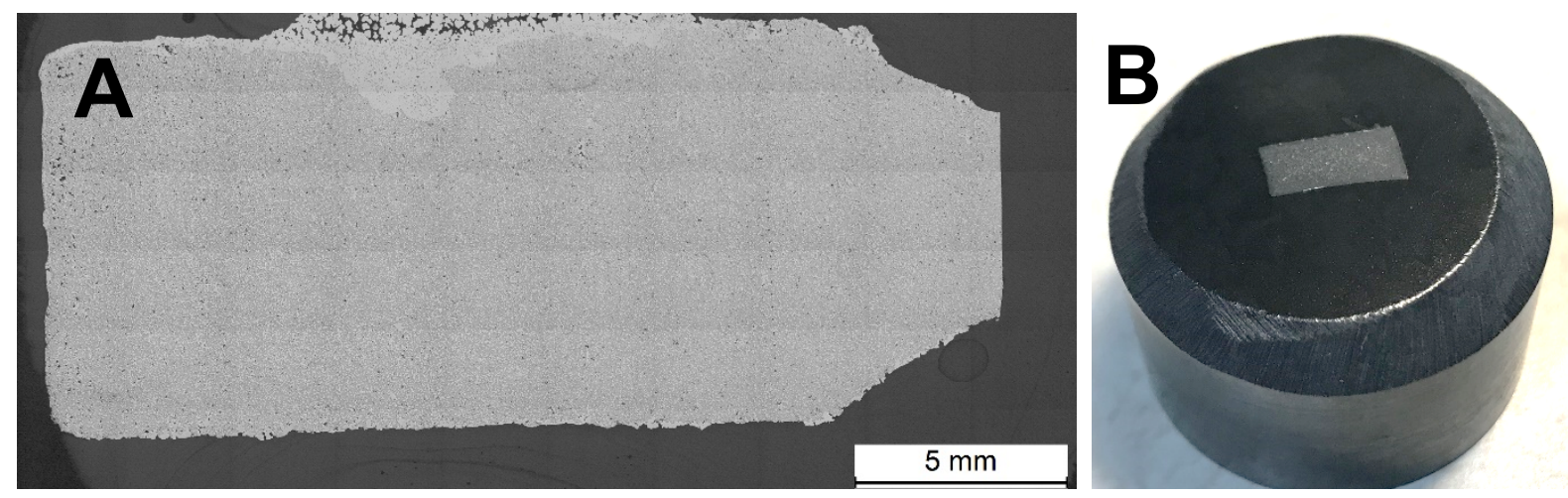

Figure 2. A) Polished surface and B) Mounting used for polishing.

The polished sample of stainless steel with infiltrated bronze was tested for its surface roughness. The sample was measured using a Surftest SJ-210 profilometer to directly collect data on the sample's surface to see if a standard polishing procedure could achieve a SPI A-1 surface finish.

The SPI A-1 surface finish states that the Roughness Average (Ra) value should be anywhere from 0-1 $\mu \mathrm{in}$. This is typically achieved using a Grade \#3 diamond buff. The finish of the part needs to be this fine to create a smooth surface for using the part as an injection molding tool. A surface finish that is too rough will cause unwanted blemishes on the molded part as well as make the molded part harder to separate from the mold.

The test was carried out using the profilometer, calibration plate, and the infiltrated sample. First, the profilometer and calibration plate were set up on an included specimen stage. Once calibrated, the test was carried out by adjusting the settings to measure 10 samples at 0.01 -inch intervals at the slowest allowed speed of 0.01 inches per second. The slowest speed was used to obtain the most accurate surface roughness profile possible. The length was selected based on both limitations by the sample size and unit. 
A built-in gauss filter was used to filter the surface roughness profile and stay in line with the most standards allowed.

The parameters used for reporting surface finish are the Roughness Average (Ra), Root Mean Square Roughness (Rq), and Average Maximum Height of the Profile (Rz) values. These three values are included in this report as they are the most commonly used measurement parameters for surface roughness. According to the Mitutoyo Surftest SJ-210 manual pages 18-18 - 18-19, "Ra is the arithmetic mean of the absolute values of the evaluation profile deviations (Yi) from the mean line. Rq is the square root of the arithmetic mean of the squares of the deviations (Yi) from the mean line to the evaluation profile. You find the Rz by dividing the evaluation profile segments based on the sampling length. Then, for each segment, obtain the sum (zi) of the highest point from the mean line (Pi) and the lowest point from the mean line (Vi). The average of these sums is Rz, Rmax (for JIS1982), or Ry (for JIS 1994).” [2]

The following table is a report on the $\mathrm{Ra}, \mathrm{Rq}$, and $\mathrm{Rz}$ values at the various sample intervals $(\mathrm{N})$ as well as the average value over the entire length (Final Value).

Table 1. $\mathrm{Ra}, \mathrm{Rq}$, and $\mathrm{Rz}$ value report.

\begin{tabular}{|c|c|c|c|}
\hline $\mathrm{N}$ & $\begin{array}{c}\mathrm{Ra} \\
(\mu \mathrm{in})\end{array}$ & $\mathrm{Rq}(\mu \mathrm{in})$ & $\mathrm{Rz}(\mu \mathrm{in})$ \\
\hline 1 & 4.94 & 6.44 & 32.54 \\
\hline 2 & 3.37 & 4.76 & 22.6 \\
\hline 3 & 5.74 & 7.21 & 26.58 \\
\hline 4 & 4.16 & 6.22 & 43.3 \\
\hline 5 & 5.08 & 6.19 & 23.97 \\
\hline 6 & 7.07 & 8.6 & 33.41 \\
\hline 7 & 5.08 & 5.94 & 21.86 \\
\hline 8 & 5.5 & 6.8 & 25.63 \\
\hline 9 & 7.21 & 8.54 & 32.51 \\
\hline 10 & 8.48 & 9.54 & 33.18 \\
\hline Final Value & $\mathbf{5 . 6 6}$ & $\mathbf{7 . 0 2}$ & $\mathbf{2 9 . 5 6}$ \\
\hline Required Value for Automotive Lighting & \multicolumn{3}{|l}{ 0 to 1 uin } \\
\hline
\end{tabular}

This table indicates that measured roughness of the polished bronze-steel is outside of the $0-1 \mu$ in range of Ra required to meet the SPI A-1 standard finish for our polished sample. In fact, our polishing technique doesn't meet with the SPI B standards that go up to $5 \mu \mathrm{in}$. A potential reason for this is the difference in hardness between the stainless steel and the bronze, which can induce uneven polishing. Another potential reason for this is the porosity found in the part. In Figure 3 (below), the data reporting from the Surftest instrument is shown. 


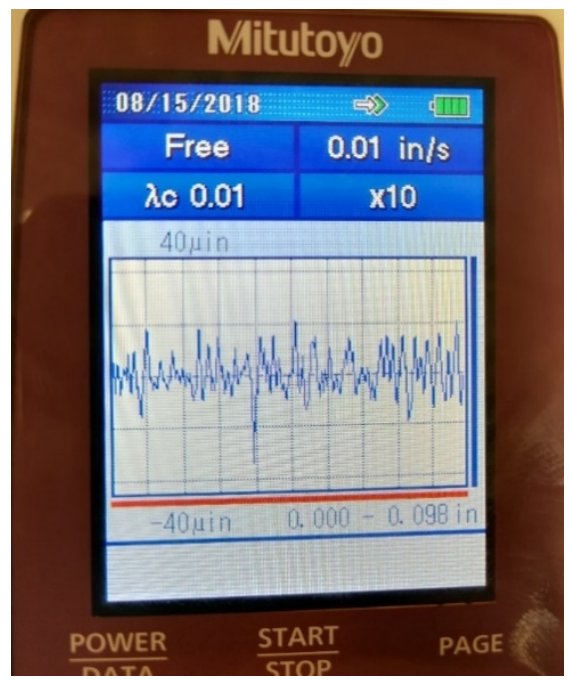

Figure 3. Surface roughness profile.

Previously acquired data on Stainless Steel 316 infiltrated with bronze binder jetted components supports the hypothesis that the two materials polish unevenly. Figure 4 is an optical image showing the stainlesssteel printed particles in grey/white and the infiltrated bronze in yellow.



Figure 4. Cross Section of Printed and Infiltrated SS316. Shadows indicate uneven material removable during polishing. 


\subsubsection{Mold Design, Manufacture, and Polishing}

After the initial polished sample had its surface finish tested, the team designed, manufactured, and polished some molds using methods developed by the industry partner, Grote. The component was a mold that could be used to fabricate components of automotive lights. The mold's design was provided by Grote. The ORNL team optimized the mold's design for additive manufacturing (Figure 5).
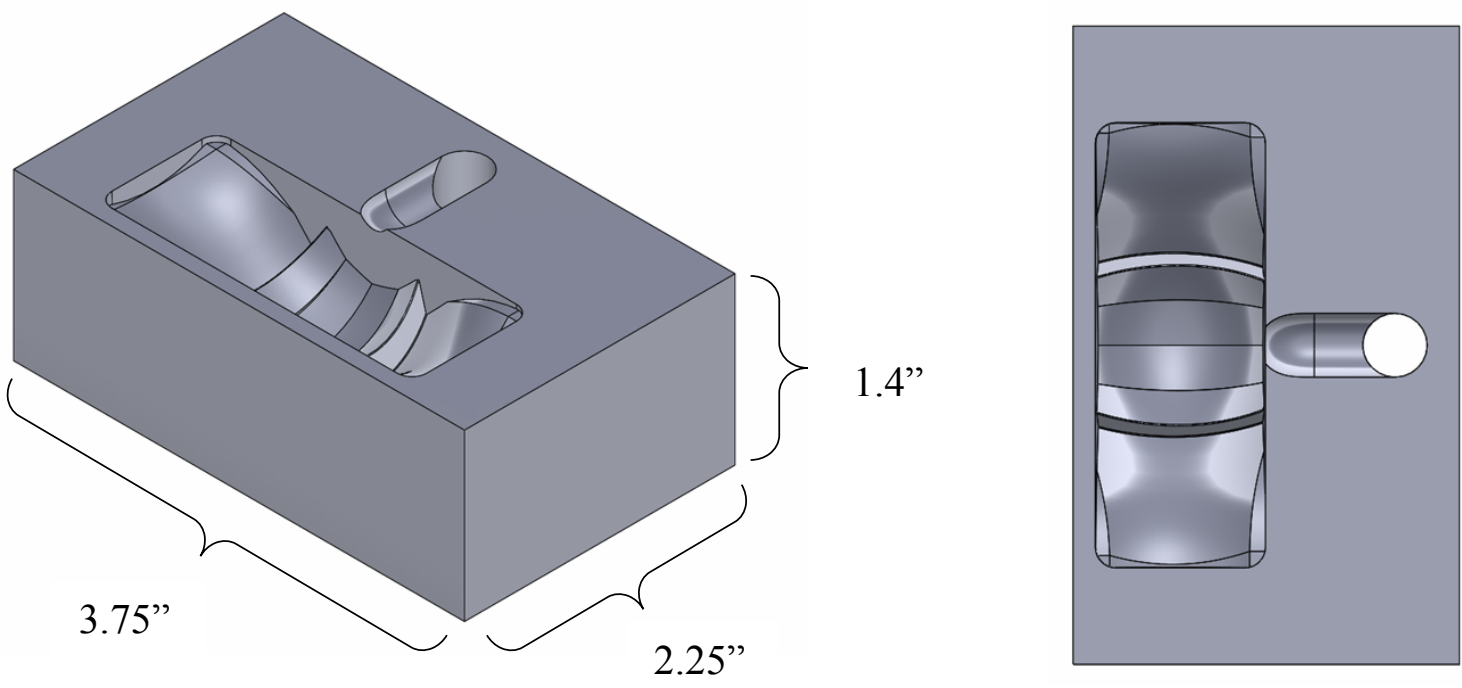

Figure 5. Final mold design.

After the design was complete, the component was fabricated from stainless steel using a binder jet system. The mold was then infiltrated with bronze to finish its fabrication, just as the test sample was (Figure 6).

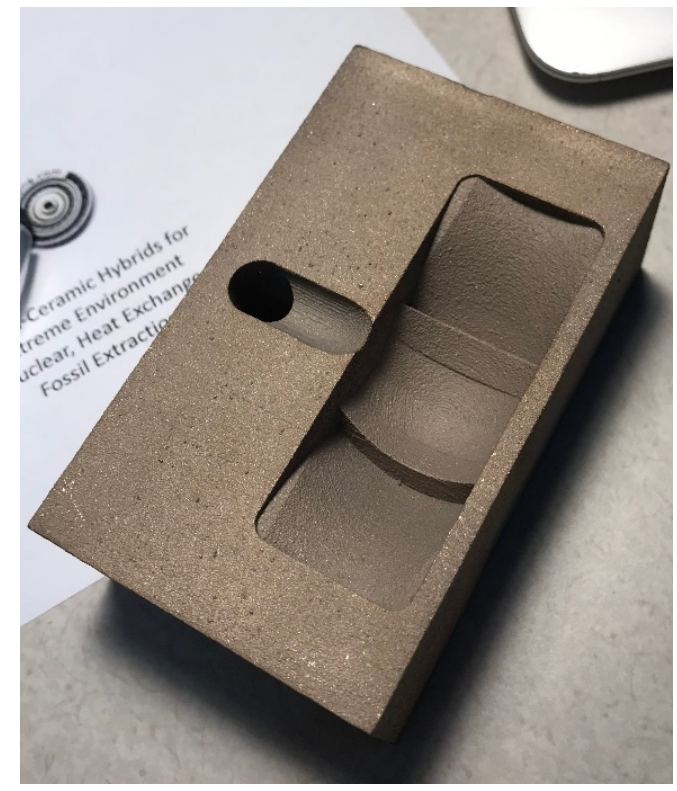

Figure 6. One half of the fabricated mold prior to polishing. 
ExOne provided a quote for the mold if they were to fabricate it that amounted to $\$ 324.16$ per piece (See Appendix A). Six items were quoted to provide multiple test samples for the study.

Next, the mold was polished by Grote. The first polishing approach used was a traditional technique comprised of several rounds of sanding using sandpaper with gradually increasing fineness of grit, and the process was finished out with two rounds of diamond buffing. Figure 7 shows the polished mold surface, and the steps of the sanding are listed below.

1. Flatten out with diamond file

2. Polished with ultrasonic polisher

3. Polished with 320 grit sandpaper

4. Polished with 400 grit sandpaper

5. Polished with 600 grit sandpaper

6. Polished with 1000 grit sandpaper

7. Polished with 1200 grit sandpaper

8. Polished with 6-micron diamond compound

9. Polished with 3-micron diamond compound

This polishing process took a total of 45 hours. After the sandpaper steps, the mold appeared to be doing well with no visible defects on the surface. However, after diamond buffing in an attempt to achieve an A-1 mirror finish, defects or divots appeared in the mold's surface. This could be caused by porosity remaining in the part. Therefore, alternative methods of polishing were explored.

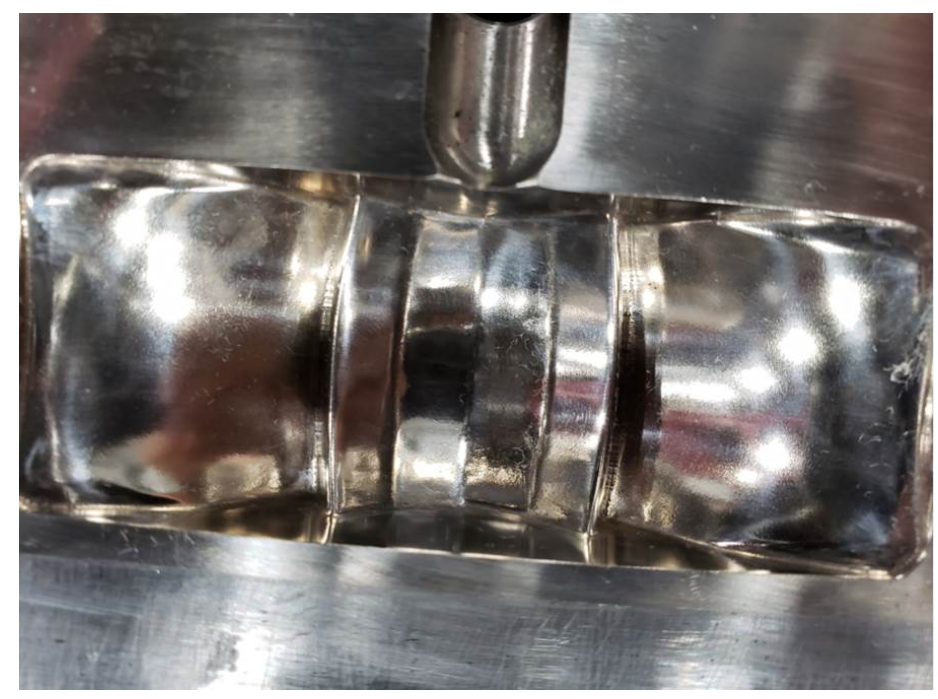

Figure 7. Mold surface after polishing.

Surface finish polishing was attempted by electrochemistry and chemical polishing methods. Both approaches preferentially etched bronze phase more aggressively than steel. As a result, surface roughness increased. From these polishing attempts, it was learned that chemical-based surface finishing may not be the right approach for composite materials. A successful approach may be to briefly etch the surface, add a material, such as nickel, to the surface, and then electro-polish it to achieve the necessary surface finish. 


\subsection{IMPACTS}

Tooling is a major portion of the manufacturing market and provides many jobs, and most tooling is now manufactured in Asia using traditional methods. An opportunity exists to "leap-frog" current tool manufacturing technology by utilizing AM. This project aimed to provide insight and confidence for Grote, and other U.S.-based manufactures, to begin using AM to re-shore tooling manufacturing for their product lines, decreasing manufacturing costs, decreasing lead times and increasing competitiveness.

\subsubsection{SUBJECT INVENTIONS}

There are no subject inventions as a result of this project.

\subsection{CONCLUSIONS}

This project sought to achieve an SPI A-1 surface finish on additively manufactured tooling used to produce automotive lighting products. The project explored the use of metal powder bed systems to rapidly manufacture moderate sized injection molding tools (less than 8 " x 8" x 2"). Various polishing techniques were explored: traditional sanding, electrochemical, and chemical. Unfortunately, traditional sanding revealed porosity in the final component resulting in a less than desirable surface finish. Both electrochemical and chemical polishing approaches preferentially etched bronze phase more aggressively than steel. However, a potential path forward may be to briefly etch the surface, add a material such as nickel to the surface, and then electro-polish it to achieve the necessary surface finish. Follow-up research is required to determine the true viability of this method. 


\section{GROTE INDUSTRIES, LLC BACKGROUND}

Grote Industries, LLC is a 115-year-old fourth generation family business that designs, manufactures, and distributes lighting systems for the transportation industry. Grote produces signal lamps such as LED tail and marker lamps, LED Headlamps, LED and halogen work lamps, and LED interior lamps for commercial and passenger vehicles. The company is based in Madison, Indiana.

\section{REFERENCES}

1. "Stainless Steel Polishing Techniques." Metallography 300 \& 400 series Stainless Steel. Pace Technologies. Accessed December 17, 2019. https://www.metallographic.com/MetallographicPreparation-Procedures/Stainless-Steel-400-series.htm.

2. Mitutoyo Surftest SJ-210 Manual, pages 18-18 - 18-19.

\section{APPENDICES}

\subsection{APPENDIX A: QUOTE FROM EXONE}

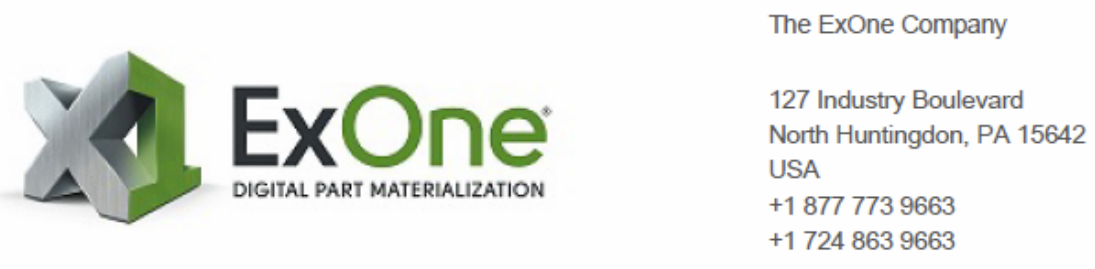

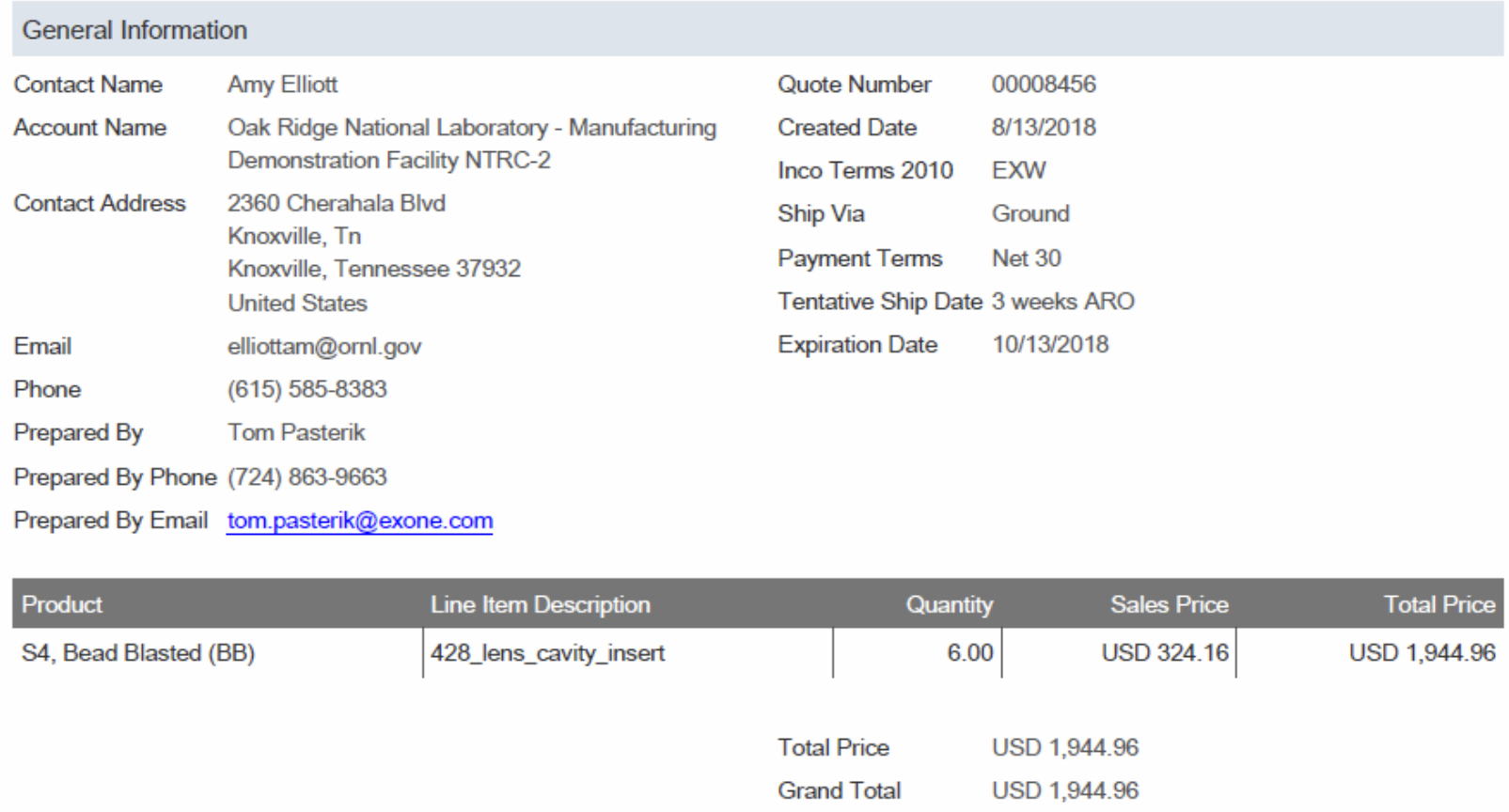




\subsection{APPENDIX B: PROCESS SHEET}

\section{PROCESS SHEET}

Project Code: _ 3D Printed Mold $1 / 15 / / 2019$

\begin{tabular}{|c|c|c|c|c|c|c|c|c|}
\hline S/No & $\begin{array}{l}\text { Operation } \\
\text { Description } \\
\text { (Process) }\end{array}$ & $\begin{array}{l}\text { Approx. Time } \\
\text { to Complete }\end{array}$ & $\begin{array}{c}\text { Drawing } \\
\text { Code, No, } \\
\text { Shape } \\
\end{array}$ & $\begin{array}{c}\text { Tolerance/ } \\
\text { Fits } \\
\text { /Allowance }\end{array}$ & Name of Machine, Tools & $\begin{array}{l}\text { Material \& } \\
\text { Size }\end{array}$ & $\begin{array}{l}\text { Quality } \\
\text { Control }\end{array}$ & Remarks \\
\hline 1 & $\begin{array}{l}\text { Remove all high } \\
\text { spots }\end{array}$ & $6-7 \mathrm{hrs}$ & & & $\begin{array}{l}\text { Flat belt, coarse diamond } \\
\text { bits }\end{array}$ & 120 grit & & \\
\hline 2 & Bead blast & $1 / 2 \mathrm{hr}$ & & & Glass bead & .5 micron & & $\begin{array}{l}\text { This will show all } \\
\text { imperfections }\end{array}$ \\
\hline 3 & Grind & $6-8 \mathrm{hrs}$ & & & $\begin{array}{l}\text { Diamond bits of various } \\
\text { sizes and shapes }\end{array}$ & 600 grit & & \\
\hline 4 & Bead blast again & $1 / 2 \mathrm{hr}$ & & & Glass bead & .5 micron & & Showing any major flaws \\
\hline 5 & Polish & $6-7 \mathrm{hrs}$ & & & $\begin{array}{c}\text { Diamond bits of various } \\
\text { sizes and shapes }\end{array}$ & 1200 grit & & \\
\hline 6 & Bead blast \#3 & $1 / 2 \mathrm{hr}$ & & & Glass bead & .5 micron & & \\
\hline 7 & Polish & $5-6 \mathrm{hrs}$ & & & $\begin{array}{c}\text { Diamond bits of various } \\
\text { sizes and shapes }\end{array}$ & 3000 grit & & \\
\hline 8 & Bead blast \#4 & $1 / 2 \mathrm{hr}$ & & & Glass bead & .5 micron & & \\
\hline 9 & Polish & $6-7 \mathrm{hrs}$ & & & $\begin{array}{c}\text { Diamond bits of various } \\
\text { sizes and shapes }\end{array}$ & 6000 grit & & \\
\hline 10 & Buff & $5-7 \mathrm{hrs}$ & & & $\begin{array}{l}\text { Various buff wheels and } \\
\text { stainless-steel compound }\end{array}$ & SS compound & & $\begin{array}{l}\text { Also doing any touch up work } \\
\text { to get an A2 finish }\end{array}$ \\
\hline 11 & Shine & $1 \mathrm{hr}$ & & & $\begin{array}{c}\text { Final cloth buff wheel } \\
\text { w/compound }\end{array}$ & $\begin{array}{l}\text { Coloring } \\
\text { compound } \\
\end{array}$ & & \\
\hline 12 & Total manhours & $36-44 \mathrm{hrs}$ & & & & & & \\
\hline
\end{tabular}

